\title{
$\begin{array}{ll}\text { Research Square } & \begin{array}{l}\text { Preprints are preliminary reports that have not undergone peer review. } \\ \text { They should not be considered conclusive, used to inform clinical practice, } \\ \text { or referenced by the media as validated information. }\end{array}\end{array}$
}

\section{Optimal Land And Water Allocation Model For The Maximization of Net Agricultural Return In Drought Prone Regions}

Mulu Sewinet Kerebih ( $\nabla$ mulusewt@gmail.com )

Debre Markos University https://orcid.org/0000-0002-6634-2447

\section{Ashok Kumar Keshari}

IITD: Indian Institute of Technology Delhi

\section{Research Article}

Keywords: linear optimization model, land and water resources optimal allocation, optimal cropping pattern, dependable rainfall

Posted Date: December 28th, 2021

DOI: https://doi.org/10.21203/rs.3.rs-976053/v1

License: (c) (i) This work is licensed under a Creative Commons Attribution 4.0 International License. Read Full License 


\section{Abstract}

In this study, the land and water resources allocation model was developed to determine optimal cropping patterns and water resources allocations at different rainfall probability exceedance levels (PEs) to ensure maximum agricultural return in the Hormat-Golina valley irrigation command area, Ethiopia. To account the uncertainty of rainfall variability, the monthly dependable rainfall was estimated at three levels of reliability $(20,50$ and $80 \%$ PEs) which are representing wet, normal and dry seasons based on regional experience. The irrigation water demand which was used as an input to the optimization model was estimated at each level of reliability by using CROPWAT model. The net annual returns of optimal cropping patterns were estimated as 181, 179 and 175 million Ethiopia Birr at $20 \%, 50 \%$ and $80 \%$ PEs, respectively. The result of the optimal cropping pattern indicates that, the net annual return of the command area was increased to $45.75 \%, 45.84 \%$ and $47.01 \%$ than the Government targeted at $20 \%, 50 \%$ and $80 \%$ PEs, respectively. The findings reveal that the optimal land and water resources allocation model is very useful to the planners and decision makers to maximize the agricultural return particularly in areas where land and water resources are limited.

\section{Introduction}

The agriculture productivity has to be increased to fulfill the rising food requirement of the population[1];[2];[3]). This is possible through cultivating more area or effective management of available land and water resources. Increasing cultivation area is difficult due to limitations of the land area being cultivated and it brings environmental disturbance. Particularly, in arid and semi-arid regions, the land and water resources are limited [4]; [5] and food insecurity has become a critical issue especially in developing nations like Africa, Ethiopia. Therefore, both land and water resources should be allocated optimally under a multi-crop situation in a crop growing season for the maximization of net agricultural returns [6]; [7].

In irrigated agriculture, where various crops are competing for a limited quantity of land and water resources, the use of linear programming is one of the best alternative optimization tools for the effective utilization of both resources in sustainable manner [8];[9]. The linear programing is also easy to apply for the optimal allocation of available land and water resources to maximize farm revenue from agricultural fields [10]. Sethi et al. [8] developed linear optimization model for optimal cropping and groundwater management for maximizing the economic return of agricultural products. Crop planning model was developed by Itoh et al. [12] which support decision making of agricultural farms. Vedula et al. [13] presented mathematical model to arrive at an optimal conjunctive use policy for irrigation of multiple crops in a reservoir-canal-aquifer system. The deterministic linear programing and chance-constrained linear programming models were developed by Sethi et al. [13] to allocate available land and water resources optimally on seasonal basis to maximize the net annual return from intensive rice cultivation agricultural fields. Adeyemo \& Otieno [13] developed multi objective crop planning model to minimize the total irrigation water and to maximize the total net income in a farmland. A linear programming model was presented by [4] for the optimal land and water resources allocation in order to maximize net annual returns. The model was applied in arid and semi-arid regions where good quality soil and water resources are limited.

A simulation and optimization models was developed by [3] for the optimal planning of cropping pattern, maximization of net benefits and minimization of irrigation water requirements. Singh [9]presented a linear programming model for the optimal land and water resources allocation in order to maximize net annual returns from an irrigated area located in Haryana State of India. The model incorporates reservoir inflow uncertainty but 
lacks stream-aquifer interaction and seepage through water conveyance (canals) structures as well as conjunctive use of water resources. Jiang et al. [15] developed process-based regional economic optimization model for maximizing irrigation water use efficiency and economic benefit of an irrigation system. A linear optimization model was developed by [16] to maximize the net annual return from the three old regions of Egypt.

Mahmoudzadeh Varzi et al. [17] presented optimization model to maximize farm profit through optimizing water allocation between on-farm production and off-farm leases. The presented model optimizes the water allocation for a single farm and crop using crop water production functions and the concept of deficit irrigation.

Almost in all the previous studies ([13];[3]; [9], the optimization models were applied to maximize agricultural returns without considering hydrological uncertainty and linkage of stream-aquifer for quantifying hydrological responses. The cropping pattern and irrigation water requirement in the command area are governed by the various hydrologic uncertainties such as special and temporal variation of rainfall. Rainfall is an important parameter that drives many hydrological processes and it is one of the main sources of uncertainty in hydrological process responses ([18]; [19]; [20]; ; [21]; [22]). Therefore, management models that are incorporating the uncertainty of a hydrological process are becoming a more reliable tool for irrigation planning and optimal allocation of limited resources. [23]) developed a chance constrained linear programming model to optimize cropping pattern of major crops grown at Koga irrigation scheme, Ethiopia. The model incorporates hydrological uncertainties. An optimal land and water resources allocation model incorporating hydrologic uncertainty was developed by Raul et al., 2011) to determine the optimal cropping pattern for maximizing net annual return. [6] presented an irrigation scheduling model and a linear-programming optimization model under hydrologic uncertainty with a view to manage the available land and water resources of the canal command effectively in canal command of the Hirakud multipurpose major irrigation project of Orissa in eastern India. The recent literature shows growing interest in the use of optimization techniques for optimal allocation of available land and water resources, although they differ significantly in terms of optimization technique, hydrological processes involved, scale of detailing and complexity, and application area ([25]; [26]; [27] [9]; [28]; [29]).

In the present study, a linear optimization model has been formulated for maximizing the net annual return of the crops subjected to various land and water resources constraints. The developed management model incorporates hydrological uncertainty by varying exceedance probability of rainfall, linkage of stream-aquifer for quantifying hydrological responses, and the constraints due to land availability, crop water requirement, irrigation water availability and prevailing farmer's willingness and cropping practices. The present study is first of its kind in the study area and aimed to evolve optimal cropping pattern and water resources allocation policies in the area.

\section{Formulation Of Optimal Allocation Optimization Model}

In the present study, a linear optimization model has been formulated for maximizing the net annual return of the crops subjected to various land and water resources constraints. The management model has been used to find out the optimal land (cropping pattern) and water resources (groundwater and surface water) allocation policies. Mathematically, the objective function of land and water resources allocation model can be expressed as:

$$
\operatorname{Max} Z_{p}=\sum_{i=1}^{2} \sum_{j=1}^{n}\left(P_{i j} Y_{i j}-C_{i j}\right) a_{i j}-\sum_{i=1}^{2}\left(C_{s w}(S W)_{i}+C_{g w}(G w)_{i}\right)(1)
$$


Where $Z_{p}$ is the net total annual income from crops in Birr (Ethiopia currency; US\$ 1=41.2 Birr); i is index for crop season ( $\mathrm{i}=1$ for rainy season and $\mathrm{i}=2$ for non-rainy season); $\mathrm{n}$ is the total number of crops grown in a crop season $(n=6$ for $i=1$ and $n=7$ for $i=2) ; P_{i j}$ is market price of the $j^{\text {th }}$ crop grown in season $i\left(B i r r g^{-1}\right) ; Y_{i j}$ is yield of the $j^{\text {th }}$ crop grown in $\mathrm{i}^{\text {th }}$ season $\left(\mathrm{kg} \mathrm{ha}^{-1}\right)$; $\mathrm{C}_{\mathrm{ij}}$ is cost of cultivation per unit area for the jth crop excluding the cost of irrigation water grown with a crop season i (Birr ha $\left.{ }^{-1}\right) ; a_{i j}$ is area allocated to crop j grown in season i (ha); $C_{S W}$ is the cost of surface water (birr/m $\left.\mathrm{m}^{3}\right) ; C_{g w}$ is the cost of groundwater (Birr/m $\left.{ }^{3}\right) ;(S W)_{i}$ is the allocation of surface water in season $\mathrm{i}\left(\mathrm{m}^{3}\right)$, a decision variable; $(G w)_{i}$ is the allocation of groundwater in season i $\left(\mathrm{m}^{3}\right)$, a decision variable.

The net incomes of crops were calculated from the potential yield of crops, market price of crops and the cost of cultivation. The yield estimates for individual crops are based on the historical performance of the farm, yield potential of the crops, recorded yields of trial and demonstrations, improved cultural practices and efficient management. The current yields of crops were taken from the agronomy feasibility report of Kobo-Girana pressurized irrigation project (Kobo-Girana pressurized irrigation project crop agronomy feasibility unpublished report, 2007). The cost of cultivation of different crops was estimated mainly in consultation of the local farmers and Woreda and Zonal government institutions including agricultural and other pertinent offices. The cost of cultivation includes seed cost, fertilizer, plant protection, draft power and labor costs. The cost of land was not considered in cost of cultivation since it belongs to farmers own land. The administration costs, such as salary of experts, telephone service costs and so on were not considered as it is covered by the Kobo-Girana pressurized irrigation project and Wereda Agricultural Administration Offices. The unit costs of agricultural crops of the local area were taken from Central Statistical Agency of Ethiopia. Since there is no fixed water tariff rate for irrigation paid by the beneficiaries in the study area, the water tariff rate was considered from the other areas having similar water sources. Thus, the costs of canal water were considered as 3 Ethiopian Birr per $1000 \mathrm{~m}^{3}$ of water which is irrigation canal water tariff of nearby basin (Awash river basin) ([30] and the cost of groundwater were assumed 3.8 Ethiopian Birr per $\mathrm{m}^{3}$ which is the water tariff of Addis Ababa Town for non-domestic purposes. Summary of cost and net return of dry and wet season crops is shown in Table 1. 
Table 1

Summary of cost and net return of Dry and Wet season crops

\begin{tabular}{|c|c|c|c|c|c|c|c|c|}
\hline No & Crop & $\begin{array}{l}\text { Grain } \\
\text { yield(Birr/ha) }\end{array}$ & $\begin{array}{l}\text { fertilizer } \\
\text { (Birr/ha) }\end{array}$ & $\begin{array}{l}\text { Seed } \\
\text { rate } \\
\text { (Birr/ha) }\end{array}$ & $\begin{array}{l}\text { plant } \\
\text { protection } \\
\text { (Birr/ha) }\end{array}$ & $\begin{array}{l}\text { Labor } \\
\text { cost(Birr/ha) }\end{array}$ & $\begin{array}{l}\text { Draft } \\
\text { power } \\
\text { (Birr/ha) }\end{array}$ & $\begin{array}{l}\text { Net } \\
\text { return } \\
\text { (Birr/ha) }\end{array}$ \\
\hline & $\begin{array}{l}\text { Dry } \\
\text { season }\end{array}$ & & & & & & & \\
\hline 1 & $\begin{array}{l}\text { Maize } \\
\text { (dry) }\end{array}$ & 44475 & 1291 & 148 & 240 & 1260 & 600 & 40936 \\
\hline 2 & $\begin{array}{l}\text { Haricot } \\
\text { bean }\end{array}$ & 17525 & 1116 & 351 & 90 & 1980 & 960 & 13029 \\
\hline 3 & $\begin{array}{l}\text { Ground } \\
\text { nut }\end{array}$ & 59570 & 744 & 2072 & 90 & 1666 & 497 & 54501 \\
\hline 4 & Onion & 204160 & 2309 & 111 & 90 & 2700 & 480 & 198470 \\
\hline 5 & Tomato & 480000 & 2035 & 10 & 70 & 3300 & 480 & 474105 \\
\hline \multirow[t]{2}{*}{6} & Pepper & 36340 & 1882 & 27 & 60 & 3540 & 480 & 30351 \\
\hline & $\begin{array}{l}\text { Wet } \\
\text { season }\end{array}$ & & & & & & & \\
\hline 1 & Sorghum & 44223 & 1291 & 84 & 240 & 1380 & 960 & 40268 \\
\hline 2 & Teff & 31786 & 567 & 319 & 93 & 2310 & 1440 & 27057 \\
\hline 3 & $\begin{array}{l}\text { Maize } \\
\text { (wet) }\end{array}$ & 30836 & 1291 & 148 & 240 & 1260 & 600 & 27297 \\
\hline 4 & Chickpeas & 14720 & 446 & 1426 & 120 & 1620 & 1200 & 9908 \\
\hline 5 & $\begin{array}{l}\text { Mung } \\
\text { bean }\end{array}$ & 25024 & 441 & 1523 & 100 & 1680 & 1200 & 20080 \\
\hline 6 & Sesame & 57954 & 790 & 406 & 80 & 1620 & 1200 & 53859 \\
\hline 7 & $\begin{array}{l}\text { Sweet } \\
\text { potato }\end{array}$ & 180000 & 2232 & 500 & 60 & 1860 & 480 & 174868 \\
\hline
\end{tabular}

\subsection{Model Constraints}

Land availability constraints

Land allocated to various crops in different seasons must not exceed the total avialable land. This limit ratio can be expressed as:

$$
\sum_{j=1}^{n} a_{i j} \leq A_{i} \forall i(2)
$$

Where $A_{i}$ is the total caltivated command area in season $i$

Water requirement constraint 
The gross irrigation requirement of all the crops grown in the irrigation command area in all the seasons must satisfy the available quantity of groundwater and diverted surface water resources. It can be expressed as:

$$
\sum_{j=1}^{n} a_{i j} *\left(G I R_{i j}\right) * 10 \leq\left(E_{g w}(G w)_{i}+E_{S W}(S w)_{i}\right) \forall i(3)
$$

Where $G I R_{i j}=$ growth irrigation requirement of crop j grown in season i $(\mathrm{mm}) ; a_{i j}=$ area

allocated to crop j grown in season i (ha); $E_{S W}=$ conveyance efficiency of surface water ; $E_{g w}=$ conveyence efficiency of groundwater; $(S W)_{i}=$ allocation of surface water in season i $\left(\mathrm{m}^{3}\right)$; and $(G W)_{i}=$ allocation of groundwater in season $\mathrm{i}\left(\mathrm{m}^{3}\right)$. In this study, conveyance efficiency of surface water and groundwater were asummed as $98.2 \%$ and $100 \%$, respectively (Belay, 2012).

The allocation of groundwater and surface water must not exceed their seasonal avialablity

$$
\begin{aligned}
(G W)_{i} & \leq \sum_{\xi=1}^{43} \sum_{k=1}^{6}\left(Q_{g w}\right)_{\xi, k} *\left(\Delta t_{p}\right)_{k} * 5.4 * 10^{4} \text { fori }=1(4) \\
(G W)_{i} & \leq \sum_{\xi=1}^{43} \sum_{k=1}^{5}\left(Q_{g w}\right)_{\xi, k} *\left(\Delta t_{p}\right)_{k} * 5.4 * 10^{4} \text { fori }=2(5) \\
(S W)_{i} & \leq \sum_{k=1}^{5}\left(Q_{S D}\right)_{i, k} *\left(\Delta t_{d}\right)_{k} * 8.64 * 10^{4} \text { fori }=1(6) \\
(S W)_{i} & \leq \sum_{k=6}^{12}\left(Q_{S D}\right)_{i, k} *\left(\Delta t_{d}\right)_{k} * 8.64 * 10^{4} \text { fori }=2(7)
\end{aligned}
$$

Where $\left(\mathrm{Q}_{\mathrm{gw}}\right)_{\xi, \mathrm{k}}$ is groundwater pumping from well $\xi$ in the time period $\mathrm{k}\left(\mathrm{m}^{3} / \mathrm{s}\right),\left(\mathrm{Q}_{\mathrm{SD}}\right)_{\mathrm{l}, \mathrm{k}}$ is

diversion from stream reach 1 in time period $\mathrm{k}\left(\mathrm{m}^{3} / \mathrm{s}\right),\left(\Delta t_{p}\right)_{k}$ is pumping time in the $\mathrm{k}^{\text {th }}$ time period (for example, number of days of groundwater pumping in the $\mathrm{k}^{\text {th }}$ month), $\left(\Delta t_{d}\right)_{k}$ is diversion time in the $\mathrm{k}^{\text {th }}$ time period (for example, number of days of stream diversion in the $k^{\text {th }}$ month) and $i$ is the number of growing seasons in a year. In the present study area, the crop growing seasons is 2 . The first crop growing season (dry season) is from December to May and the second crop growing season (wet season) is from July to November. All the wells assumed to be operated for 15 hours per day and the stream flow diversion for 24 hour per day. The maximum seasonal availability limit of groundwater and surface water resources was obtained from the conjunctive water use simulation-optimization model [31].

Minimum and maximum area constraints 
There could be some limitations in the area under a particular crop depending upon the past practices, food requirment, land suitablity, water avialablity and agricultural income. It can be expressed as lower and upper bounds.

$$
A_{j}^{l} \leq \sum_{i=1}^{2} a_{i j} \leq A_{j}^{u} j=1,2,3 \ldots \ldots \ldots . .14(8)
$$

Where $\mathrm{A}_{\mathrm{j}}^{\mathrm{l}}$ is the minimum area under the $\mathrm{j}^{\text {th }}$ crop, and $A_{j}^{u}$ is the maximum area under the $\mathrm{j}^{\text {th }}$ crop.

The maximum and minimum areas were set on the consideration of farmer's knowledge on cultural practices of crops and basic food requirements of the local farmers. Based on these criteria, the maximum area was fixed as $50 \%$ more than the target area, and the minimum area was set as one quarter of the target area.

\section{Model Application}

\subsection{Description of the Study Area}

The study area, Hormat-Golina sub- basin is located in the northern part of Ethiopia, $580 \mathrm{~km}$ far away from the capital Addis Ababa, Ethiopia. Geographically situated in $11^{\circ} 59^{\prime} 00^{\prime \prime}$ to $12^{\circ} 09^{\prime} 00^{\prime \prime}$ north latitude and $39^{\circ} 36^{\prime} 00^{\prime \prime}$ to $39^{\circ} 46^{\prime} 00^{\prime \prime}$ east longitude (Fig. 1). The total area covers $145 \mathrm{~km}^{2}$ and it is mostly plain area with flat topography having elevation ranging from $1640 \mathrm{~m}$ to $1339 \mathrm{~m}$ (a.m.s.l). The valley is bounded by the Alawuha sub-basin from the southern side, the Waja-Golesha Valley to the North, highly rugged mountains of Lasta from western side and extension of Zobul ridge on the eastern side. The outlet of this sub basin is the Golina stream formed through the $\mathrm{E}-\mathrm{W}$ fracture/fault line running from the Weldia-Lasta Plateau to the Zobul ridge.

The Hormat-Golina valley plain area is characterized as a semi-arid climate. The average annual temperature in the valley plain ranges from $17.5^{\circ} \mathrm{c}$ to $26^{\circ} \mathrm{C}$. In the area, two rainy seasons have been experienced; June to September as main rainy season and March to April as small rainy season. In the remaining months, it is dry. The mean annual rainfall of the watershed is $798.4 \mathrm{~mm}$ of which $80 \%$ occurs during June to September.

\subsection{Irrigation development and cropping pattern}

The low lying valley part of the Kobo watershed has been known as the most drought prone region in Ethiopia. As a result, traditional irrigation system has been practiced since long years ago before the commencement of modern irrigation. The irrigation is practiced by diverting the water from the nearby rivers of Alawuha and Golina. However, the modern irrigation has been given emphasis since 1999 in the Kobo valley due to scarcity of rainfall in the area (Co-SAERAR, unpublish report, 1999); and thereby 17000 ha of land is being proposed and start to practice for irrigation mostly from groundwater sources.

Based on this feasibility study, the cropping patterns were proposed on the basis of crop mix and area coverage of individual crops. The crop diversification has been taken as a basic criterion in establishing the crop mix and area coverage. The introduction of various crops into the cropping pattern is assumed to widen the economic base of the project and minimize the risks associated with the growing of a single or limited number of crops. The cropping pattern for the proposed irrigation command area modified from the agronomic report of Kobo-Girana valley pressurized irrigation report is shown in Table 2. The cropping pattern is dominated by annual food crops; 
the cereals (sorghum, maize and teff) is assumed to cover the major parts of the area having $110 \%$, followed by pulses (chick pea, haricot bean, mug bean) with 40\% and vegetables (onion, tomato, pepper and sweet potato) covers $31 \%$ and the remaining proposed area is covered by oil crops (sesame and groundnut).

Table 2

Selected cropping system (wet and dry season cropping)

\begin{tabular}{|lll|}
\hline Crop Type & Wet Season & Dry Season \\
\hline Cereals & Sorghum, Maize, Tef & Maize \\
\hline Pulses & Chickpeas, mug bean & Haricot beans \\
\hline Oil Crops & Sesame & Groundnuts \\
\hline Root Crops & Sweet Potato & - \\
\hline Vegetables & - & Onion, tomatoes, pepper \\
\hline
\end{tabular}

\subsection{Rainfall data collection and analysis}

In this study, the daily rainfall data of 15 years (1996-2010) were collected from National Meteorological Agency, Addis Ababa, Ethiopia observed at Kobo meteorological observatory station which is located within the study area. The daily rainfall data were analyzed to calculate the average monthly and annual rainfall. The bimodal distribution of rainfall seasons have been experienced in the study area. The main rainy season (end of June to September) and the short rain (March to beginning of May) account for about $66 \%$ and $12 \%$ of the annual total, respectively. The remaining months are generally dry. The highest rainfall occurs during July and August and the dry spell stretches from November to February and another dry spell in June (Fig. 2)

Rainfall plays a key role in appropriate planning and sustainable management of irrigation systems in water-short regions [32]. However, its uneven distribution requires getting knowledge about its special and temporal variability. The distribution of rainfall over the highland areas is modified by orographic effects and is significantly correlated with altitude ([33]; [34]. The study area is plain area with flat topography with an average elevation of $1465 \mathrm{~m}$ above mean sea level i.e nearly equals to Kobo Meteorological station elevation $(1470 \mathrm{~m})$. The sub-basin area is a relatively small and the spatial distribution of rainfall is strongly correlated with altitude in the region as it is stated by ([34]. The spatial variability and its impacts on the rainfall distribution are almost similar throughout the area. Hence, the rainfall data from this station can represent the rainfall amount in the study area.

Accurate estimation of the temporal distribution of rainfall and its trends are crucial input parameters for securing sustainable management of irrigation system. Since, the total rainfall received in a given period at a location is highly variable and often considered as a major source of uncertainty ([35]; [19]; [36]; [37]; [22]. The analysis of variations of rainfall specially, in arid and semi-arid regions is very crucial where rainfall is scarce and highly variable from one year to another [38]. Hence, in the present study, the 15 years of rainfall data were analyzed for investigation of annual and monthly variations of rainfall in the study area. The frequency analysis of monthly rainfall data has been carried out by using Storm water Management and Design Aid (SMADA) statistical software [39]. This software has a package which is used to carry out frequency analyses designed in different probability distribution functions such as normal, 2-parameter log-normal, 3-parameter log-normal, Pearson type III, log Pearson type III, Gumbel type 1 extremal and generalized extreme value. However, in this study the Normal and Log-normal distributions were considered for carrying out frequency analysis of historical rainfall data set. The 
reason for selecting these distributions for frequency analysis is due to the fact that they are commonly used for rainfall data analysis ([40]; [41]. The compatibility of a probability distribution can be assessed through a statistical goodness fit tests as well as graphical display such as probability plots ([42]. In the present study, the better fit probability distribution function was selected by using goodness of fit criteria (coefficient of determination $\left(\mathrm{R}^{2}\right)$, and Kolmogorov-Smirnov test). The monthly dependable rainfall values at 20,50 and $80 \%$ exceedance probabilities (PEs) were used as an input in CROPWAT Model to estimate net irrigation requirement of different crops. Based on regional experience, they are represented as monthly rainfall under wet, normal and dry scenarios, respectively.

\subsection{Calculating Crop Water Requirements}

In the present study, the computer program available in FAO Irrigation and Drainage Paper No. 56 "CROPWAT" was used for the calculation of crop water requirements of different crops ([43]. First, reference crop evapotranspiration (ETo) was computed by using FAO- Penman-Monteith (PM) method [43] in CROPWAT 8.0 model. The model requires less intensive data and can easily access databases for climate and crop characteristics. The CROPWAT 8.0 model demands meteorological data, crop data and soil data as an input for irrigation water requirement calculation. The meteorological data such as minimum and maximum temperature, humidity, sunshine and wind speed are used to calculate reference evapotranspiration. For each crop, the crop water requirement (ETc) was determined using the appropriate crop coefficient $\left(k_{c}\right)$ as:

$$
\mathrm{ET}_{\text {crop }}=\mathrm{K}_{\mathrm{C}} * \mathrm{ET}_{\mathrm{o}}(16)
$$

Where $\mathrm{K}_{\mathrm{C}}=$ crop coefficient, $E T_{O}=$ reference evapotranspiration

The values for crop coefficient $(\mathrm{Kc})$ vary with the crop, its stage of growth, growing season and prevailing water condition. In this study, crop coefficient (Kc) of various crops is obtained from FAO ([44]; [43].). The net irrigation requirements of the crops were calculated by deducting the effective rainfall from the water requirements of the crops. In the present study, the study area under consideration is semi-arid having low rainfall intensity and welldrained soil, and hence USDA-SCS method was selected for the estimation of effective rainfall [45]. For each crop, the net irrigation requirement was determined using the equation:

$$
\mathrm{NIR}=\mathrm{ET}_{\mathrm{c}}-\mathrm{R}_{\mathrm{e}}(17)
$$

\section{Results And Discussion}

\subsection{Rainfall probability of excedance (PE)}

The frequency analysis of monthly rainfall data of 15 years (1996-2010) was executed using the SMADA statistical analysis software to choose the best probability distribution. The Normal and Log-normal distributions were considered for carrying out frequency analysis of historical rainfall data set using Weibull plotting position. The SMADA statistical software has the capability of computing probability value and plotting the predicted and historical input rainfall against their probabilities. It also draws a best-fit regression straight line through the plotted probability. The predicted rainfall value corresponding to various probabilities and return periods were obtained from the probability plot at each distribution. 
The Kolmogorov-Smirnov test and $\mathrm{R}^{2}$ values of the normal and log-normal distributions in each month were estimated and reported in Table 3. The least Kolmogorov-Smirnov test value and the better $\mathrm{R}^{2}$ value which is close to one in each month have been selected as best fit distribution. Based on these criteria, the log-normal distribution is selected for the months of January, February, May, June, July, August, September, October, November and December, and for the other remaining months normal distribution is selected as best fit distribution.

Table 3

Kolmogorov-Smirnov test (K-S) and Coefficient of determination $\left(\mathrm{R}^{2}\right)$

\begin{tabular}{|lllll|}
\hline Month & Normal & \multicolumn{3}{c|}{ Log-normal } \\
\cline { 2 - 5 } & K-S test & $\mathbf{R}^{2}$ & K-S test & $\mathbf{R}^{2}$ \\
\hline January & 0.181 & 0.83 & 0.116 & 0.87 \\
\hline February & 0.288 & 0.62 & 0.151 & 0.76 \\
\hline March & 0.122 & 0.94 & 0.186 & 0.86 \\
\hline April & 0.121 & 0.83 & 0.162 & 0.84 \\
\hline May & 0.176 & 0.75 & 0.103 & 0.85 \\
\hline June & 0.240 & 0.66 & 0.164 & 0.92 \\
\hline July & 0.207 & 0.84 & 0.143 & 0.92 \\
\hline August & 0.141 & 0.84 & 0.133 & 0.93 \\
\hline September & 0.103 & 0.92 & 0.092 & 0.93 \\
\hline October & 0.241 & 0.77 & 0.127 & 0.84 \\
\hline November & 0.189 & 0.83 & 0.085 & 0.84 \\
\hline December & 0.279 & 0.68 & 0.165 & 0.79 \\
\hline * The critical K-S value at 0.05 significance level is 0.338 \\
\hline
\end{tabular}

Using the best fit probability distribution functions for different months; the probabilities of monthly dependable rainfall at 20,50 and $80 \%$ exceedance of rainfall were estimated. Based on regional experience, they are represented as monthly rainfall under wet, normal and dry scenarios, respectively. The monthly dependable rainfall at 80,50 and $20 \%$ probability exceedance levels is shown in Fig. 3 . The estimated dependable rainfall values with $80 \%$ probability exceedance (PE) are less than the mean rainfall values in both the months, whereas the dependable rainfall values with $20 \%$ PEs are more than the mean values in both the months. February is the driest month in the area and the least rainfall is estimated in both the probability exceedance levels. Whereas, August is the wettest month and highest rainfall is estimated in both probability exceedance levels. In February the estimated rainfall values are $9.22 \mathrm{~mm}, 3.49 \mathrm{~mm}$, and $1.32 \mathrm{~mm}$ at 20\%,50\%, and 80\% probability exceedance level, respectively and in August the estimated rainfall quantities are $297.75 \mathrm{~mm}, 230.44 \mathrm{~mm}, 178.38 \mathrm{~mm}$ at $20 \%, 50 \%$ and $80 \%$ probability exceedance level, respectively.

\subsection{Net Irrigation Requirements}


The net irrigation requirement of crops at different probability exceedance levels are shown in Table 4. There are two principal cropping seasons, non-rainy (January-May) and rainy (June-September) are prevailing in the study area and crops grown in the command area are categorized into dry season and wet season crops. During rainy season, rainfall is the main source of water for agricultural crops and irrigation water is required additionally to feed agricultural crops as compensation since the area is drought prone area, the rainfall is not sufficient to feed agricultural crops. During dry season irrigation is the main source of water for agricultural crops. Dry season crops are maize, haricot bean, ground nut, onion, tomato and pepper, and wet season crops are sorghum, teff, maize, chickpeas, mung bean, sesame and sweet potato. Maize is grown in both the seasons. The crop water requirement of maize in dry season is more than that in the wet season, because the irrigation water is used as a supplement during wet season in case of rainfall deficiency. Maize requires more water than the other dry season crops at both PE levels. Water requirement of chickpeas is more than the other wet season crops at $20 \%, 50 \%$ and $80 \%$ PE levels. The increase in the net irrigation requirement is observed at PE levels of $20 \%, 50 \%$ and $80 \%$ due to decrease in the effective rainfall.

Table 4

Net irrigation requirement (NIR) of different crops in $(\mathrm{mm})$

\begin{tabular}{|llll|}
\hline I. Dry season crops & \multicolumn{3}{l}{ PE levels in (\%) } \\
\cline { 2 - 4 } & 20 & 50 & 80 \\
\hline Maize & 551.1 & 613.3 & 673 \\
\hline Haricot bean & 322.3 & 381.6 & 410.1 \\
\hline Groundnut & 415.2 & 489 & 530.3 \\
\hline Onion & 412.5 & 447.1 & 468.6 \\
\hline Tomato & 406.7 & 434.4 & 506.9 \\
\hline Pepper & 442.3 & 468.7 & 497.4 \\
\hline II. Wet season crops & & & \\
\hline Surghum & 94.4 & 177 & 196.4 \\
\hline Teff & 156.3 & 234.4 & 235.5 \\
\hline Maize & 197.8 & 203.8 & 278.7 \\
\hline Chikpeas & 238.6 & 305.7 & 317.6 \\
\hline Mung bean & 93.8 & 105.5 & 144.5 \\
\hline Sesame & 92.5 & 182.2 & 185.2 \\
\hline Sweet potato & 209.10 & 214.30 & 313.20 \\
\hline
\end{tabular}

\subsection{Optimal cropping pattern}

A total of six crops (maize, haricot bean, ground nut, onion, tomato and pepper) in dry season and seven crops (sorghum, teff, maize, chickpeas, mung bean, sesame and sweet potato) in wet season were considered in the allocation model to determine the optimal cropping pattern. All these are the proposed crops in the study area in 
both the seasons by the agronomists of the Kobo-Girana pressurized irrigation Project Office. The optimization model was run to obtain the optimal cropping pattern of the selected crops at $20 \%, 50 \%$ and $80 \%$ exceedence probabilities of rainfall. The model was first run without minimum and maximum area constraints and the optimal land allocation result showed that all the available command area got diverted to tomato during dry season and sweet potato during wet season. One can see that tomatoes achieved the highest increase in its highest net return among other crops and its requirement of irrigation water is not as high as well. The net annual benefit increased by $86 \%$ and it indicates that tomato and sweet potato are the most beneficial crops in the command area in their respective seasons as compared to others. However, it could not be encouraged as it affects the overall balance of the agricultural system in the area and due to beneficiary's dietary requirements. Hence, the model was run by setting the minimum and maximum area constraints based on the farmer's knowledge on traditional practices of crops and basic food requirements in the study area.

The optimal cropping pattern of different crops in dry and wet seasons at $20 \%, 50 \%$ and $80 \%$ exceedence probabilities of rainfall are presented in Fig. 4. The result derived from the optimization model suggested that there is a large variation than the targeted cropping pattern. The dry season crops such as ground net, onion and tomato have been allotted the maximum area at all PEs. On the other hand, haricot bean and pepper have been allotted the minimum area at all PEs. The area under maize has been limited to 624 ha at all PEs in dry season. The wet season crops such as sorghum, sesame and sweet potato have been allotted to the maximum area possible, whereas chick peas have been allotted to the minimum area at all PEs. Maize has been allotted the maximum area at $20 \%$ and $50 \%$ PEs, and minimum area at $80 \%$ PEs in the wet season. On the other hand, maximum area has been allotted to mung bean at $50 \%$ and $80 \%$ PEs, and minimum area at $20 \%$ PEs. The area under teff has been limited to $204 \mathrm{ha}, 288 \mathrm{ha}$, and $321.6 \mathrm{ha}$ at $20 \%, 50 \%$ and $80 \%$ PEs, respectively, which is less than the targeted area in both cases.

Based on the results of optimal cropping pattern, the allotted area of crops such as ground net, onion, tomato, sorghum, sesame and sweet potato have increased by 50 \% than the targeted area at all PEs. On the other hand, the area under crops such as haricot bean and pepper and chick peas reduced by $33 \%$ than the targeted area at all PEs. The area under the optimal cropping pattern of maize decreases by $17.79 \%$ of the existing area at all PEs during dry seasons. Even though teff covers $35 \%$ of the total targeted area which is more than the other crops except sorghum during wet season because of food subsidence of the beneficiaries, its area under the optimal cropping pattern decreases by $73 \%, 62 \%$ and $53 \%$ of the existing area at $20 \%, 50 \%$ and $80 \%$ PEs, respectively.

\subsection{Optimal water resources allocation}

The optimum allocations of canal water and groundwater in the command area in respective seasons at different PEs are shown in Fig. 5 and 6. The optimum canal water allocated to the irrigation command area is 0.63 million $\mathrm{m}^{3}$ and 0.53 million $\mathrm{m}^{3}$ during dry season and wet season, respectively at all PEs. It is the maximum available canal water in both the seasons. The optimum allocation of canal water in both the seasons is at its maximum due to minimum canal water cost per cubic meter than the groundwater cost. This amount of water satisfies only $5.89 \%, 6.00 \%$ and $6.23 \%$ of the GIR of crops at $80 \%, 50 \%$ and $20 \%$ PEs, respectively, during dry season. It also covers $11.87 \%, 13 \%$ and $13.83 \%$ of the growth irrigation requirement (GIR) of crops at $80 \%, 50 \%$ and $20 \%$ PEs, respectively, during the wet seasons. Generally, it is very less quantity as compared to groundwater use because of limitation of existing canal capacity constraints. The optimum groundwater allocated to the command area is 10.81 million $\mathrm{m}^{3}, 10.41$ million $\mathrm{m}^{3}$ and 10.22 million $\mathrm{m}^{3}$ at $80 \%, 50 \%$ and $20 \%$ PEs, respectively, during dry season. On the other hand, it is 4.47 million $\mathrm{m}^{3}, 4.06$ million $\mathrm{m}^{3}$ and 3.83 million $\mathrm{m}^{3}$ at $80 \%, 50 \%$ and $20 \% \mathrm{PEs}$, 
respectively, during wet season. In spite of the high cost of pumping as compared to the canal water, the gain in the net annual return is due to the limited canal water availability. As the maximum canal water capacity increases the allocation of groundwater decreases and which is an indication of high cost of pumping that results into the loss of net annual return.

\subsection{Net Annual return}

The net return obtained per unit are of the allocated crops is calculated by subtracting the production of the crops from the gross profit received. The production cost includes the cost of seeds, chemicals and fertilizers, water harvesting, and labor. The net annual return of optimal cropping patterns for $20 \%, 50 \%$ and $80 \%$ PEs are estimated as 181 million, 179 million, 175 million Ethiopian Birr (1 USD=41.2 Birr), respectively. It is evident from the result that there is a gradual decrease from $20 \%$ to $80 \%$ PEs in net annual benefit from the crops due to the gradual increase of GIR irrigation requirements. The comparison of net annual returns associated with the optimal cropping pattern and the government proposed cropping pattern is shown in Fig. 7 at different PEs. The net annual return from the command area increases to $45.75 \%, 45.84 \%$ and $47.01 \%$ under the optimal cropping pattern as compared to the government targeted cropping pattern at $20 \%, 50 \%$ and $80 \%$ PEs, respectively. The increase in net annual income is primarily due to the optimal allocation of land for various crops.

\section{Discussion}

The paper presents a linear programming model to determine the optimal crop type area and water volume by source (surface water and groundwater) such that the aggregated net income (revenue minus operational costs including water extraction) of crop production is maximized. The model is formulated and applied in the study area to find out the optimal cropping pattern and optimal allocation of available irrigation water resources in most efficient way for crop production to give the maximum profitability. The optimization model incorporates hydrological uncertainty, linkage of stream-aquifer linkage for quantifying the hydrological responses, and the constraints of the model pertain to the availability of cropland area, water requirements by crop, upper bounds for water extraction volumes by source, lower and upper bounds on cropland area by crop type and prevailing farmer's willingness and cropping practices in the two different irrigation seasons of the year. The developed linear programming model was solved by utilizing MATLAB optimization tool box by writing function code or M-files with the simplex method. For more description on the optimization toolbox, readers may refer [46].

The net return of optimal cropping pattern resulting from the application of the LP model was compared to the existing net return cropping pattern. Different cropping pattern of the area with land restriction was carried out to come up with maximum net profit within available resources and it can be concluded that applying the most beneficial crops like tomato and sweet potato will significantly increase the total net benefit from the agricultural area. This increase in return will help in decision making of farmers what is actually needed to make the available land more profitable. On the other hand, keeping on cultivation of the non-profitable crops with their actual existing areas will reduce the total net benefit and it will limit the allocated areas of the profitable crops and will generally increase the production of the land to satisfy the food requirements. This is important and crucial to support planning for limited land and water resources development and management particularly in the study area and in the country as a whole.

\section{Model Assumptions}


The following assumptions were considered in developing the model: (1) The objective function and all the constraints are linear; (2) There is no spatial and temporal variation of soil physical and chemical properties; (3) The rainfall is uniformly distributed spatially over the study area (4) Agricultural inputs such as land, labour, remain uniform for any type of agriculture; (5) Each unit of land under any type of agriculture receives the same management practices for a particular crop; (6) Water quality is not considered by assuming that the water quality is not a problem in the specific area for irrigation; (7) A planning horizon of one year with monthly pumping time step was considered for the application of the developed model; and (9) The withdrawal discharge rate from pumping wells and discharge diverted from the canal is kept constant during each planning period, but vary from one planning period to the next.

\section{Conclusion}

A developed land and water resources allocation optimization model was applied to determine optimal crop pattern and water resources allocation in order to maximize the net agricultural production benefit at different rainfall probability exceedance levels at the Hormat-Golina irrigation command area. To account the uncertainty of rainfall variability,the monthly dependable rainfall at $80 \%, 50 \%$ and $20 \%$ probability exceedance was estimated by analyzing the 15 years monthly rainfall data with normal and log-normal distributions. The irrigation crop water requirements of different crops grown in the Hormat-Golina irrigation command area with dependable rainfalls at 80,50 and $20 \%$ probability exceedance was obtained by using CROPWAT model.

Results obtained for the optimal cropping pattern show that the dry season crops such as ground net, onion and tomato have been allotted the maximum area at all probability levels. On the contrary, haricot bean and pepper have been allotted the minimum area at all probability levels. The wet season crops such as sorghum, sesame and sweet potato have been allotted to the maximum area possible, whereas chick peas have been allotted to the minimum area at all probability levels. Results obtained from the water resources allocation model reveal that the optimum canal water allocated to the irrigation command area is 0.63 million $\mathrm{m}^{3}$ and 0.53 million $\mathrm{m}^{3}$ during dry season and wet season respectively, at all probability levels. Whereas the optimum groundwater allocated to the command area is 10.81 million $\mathrm{m}^{3}, 10.41$ million $\mathrm{m}^{3}$ and 10.22 million $\mathrm{m}^{3}$ at $80 \%, 50 \%$ and $20 \%$ PEs, respectively during dry season and it is 4.47 million $\mathrm{m}^{3}, 4.06$ million $\mathrm{m}^{3}$ and 3.83 million $\mathrm{m}^{3}$ at $80 \%, 50 \%$ and $20 \%$ PEs, respectively, during wet season. The developed optimization model can be used to any irrigation field as a decision support tool to assist planners, farmers and policy makers in determining the most efficient utilization of available land and water resources for the irrigated command areas.

\section{Declarations}

\section{Data Availability Statement}

Some data used in this study such as climate data, cropping agronomy data, crop coefficient data are available from the corresponding author.

\section{Acknowledgments}

The authors wish to express their thanks to Federal Demographic Republic of Ethiopia Ministry of Water and Energy, National Meteorology Agency of Ethiopia, Amhara Design and Supervision Works Enterprise (ADSWE), Kobo- Giranavalley Development program office and Kobo Wereda Agricultural and Rural Development office 
providing the necessary data used for this study free of charge. The financial support for the field visit from Debre Markos University is also gratefully acknowledged.

\section{Ethical Approval}

The manuscript is original and has not been submitted elsewhere for the consideration. Results are presented clearly, honestly, and without fabrication, falsification or inappropriate data manipulation. No data, text, or theories by others are presented.

\section{Consent to Participate}

Not applicable

\section{Consent to Publish}

Not applicable

\section{Authors Contributions}

All authors contributed to the study conception and design. Material preparation, data collection and analysis were performed by first author (Mulu Sewinet Kerebih). Drafting the work or revising it critically for important intellectual contents was carried out by second author (Proff. Ashok. K. Keshari). All authors read and approved the final manuscript.

\section{Funding}

Partial financial support for field visit was received from Debre Markos University

\section{Competing Interests}

The authors have no conflicts of interest.

\section{Availability of data and materials}

Some or all data that support the findings are available from the corresponding author upon reasonable request.

\section{References}

1. Khare D, Jat MK, Sunder JD (2007) Assessment of water resources allocation options: Conjunctive use planning in a link canal command. Resour Conserv Recycl 51(2):487-506. doi:10.1016/j.resconrec.2006.09.011

2. Singh A, "An overview of the optimization modelling applications," J Hydrol, vol. 466-467, pp. 167-182, 2012, doi:10.1016/j.jhydrol.2012.08.004

3. Darshana A, Pandey M, Ostrowski, Pandey RP (2012) Simulation and optimization for irrigation and crop planning. Irrig Drain 61(2):178-188. doi:10.1002/ird.633

4. Singh A, Panda SN (2012) Development and application of an optimization model for the maximization of net agricultural return. Agric Water Manag 115:267-275. doi:10.1016/j.agwat.2012.09.014 
5. Kerebih MS, Keshari AK (2017) GIS-Coupled Numerical Modeling for Sustainable Groundwater Development: Case Study of Aynalem Well Field, Ethiopia. J Hydrol Eng. doi:10.1061/(asce)he.1943-5584.0001444

6. Raul SK, Panda SN, Inamdar PM (2012) Sectoral Conjunctive Use Planning for Optimal Cropping under Hydrological Uncertainty. J Irrig Drain Eng 138(2):145-155. doi:10.1061/(asce)ir.1943-4774.0000393

7. Mohanty S, Jha MK, Kumar A, Brahmanand PS (2013) Optimal development of groundwater in a well command of eastern india using integrated simulation and optimization modelling. Irrig Drain 62(3):363-376. doi:10.1002/ird.1736

8. Sethi LN, Panda SN, Nayak MK (2006) Optimal crop planning and water resources allocation in a coastal groundwater basin, Orissa, India. Agric Water Manag 83(3):209-220. doi:10.1016/j.agwat.2005.11.009

9. Singh A (2016) Optimal Allocation of Resources for Increasing Farm Revenue under Hydrological Uncertainty. Water Resour Manag 30(7):2569-2580. doi:10.1007/s11269-016-1306-X

10. Moradi-Jalal M, Bozorg Haddad O, Karney BW, Mariño MA (2007) Reservoir operation in assigning optimal multi-crop irrigation areas. Agric Water Manag 90:no. 1-2. doi:10.1016/j.agwat.2007.02.013., “,”, , pp. 149159

11. Sethi LN, Kumar DN, Panda SN, Mal BC (2002) Optimal crop planning and conjunctive use of water resources in a coastal river basin. Water Resour Manag. doi:10.1023/A:1016137726131

12. Itoh T, Ishii H, Nanseki T, "A model of crop planning under uncertainty in agricultural management," 2003, doi: 10.1016/S0925-5273(02)00283-9

13. Vedula S, Mujumdar PP, Chandra Sekhar G (2005) Conjunctive use modeling for multicrop irrigation. Agric Water Manag 73(3):193-221. doi:10.1016/j.agwat.2004.10.014

14. Adeyemo J, Otieno F (2010) Differential evolution algorithm for solving multi-objective crop planning model. Agric Water Manag 97(6):848-856. doi:10.1016/j.agwat.2010.01.013

15. Jiang Y, Xu X, Huang Q, Huo Z, Huang G (2016) Optimizing regional irrigation water use by integrating a twolevel optimization model and an agro-hydrological model. Agric Water Manag.

doi:10.1016/j.agwat.2016.08.035

16. Osama S, Elkholy M, Kansoh RM (2017) Optimization of the cropping pattern in Egypt. Alexandria Eng J. doi:10.1016/j.aej.2017.04.015

17. Mahmoudzadeh Varzi M, Trout TJ, DeJonge KC, Oad R (2019) Optimal Water Allocation under Deficit Irrigation in the Context of Colorado Water Law. J Irrig Drain Eng. doi:10.1061/(asce)ir.1943-4774.0001374

18. Wagener T, Gupta HV (2005) Model identification for hydrological forecasting under uncertainty. Stoch Environ Res Risk Assess. doi:10.1007/s00477-005-0006-5

19. Cristiano E, Ten Veldhuis MC, Van De Giesen N (2017) Spatial and temporal variability of rainfall and their effects on hydrological response in urban areas - A review. Hydrol Earth Syst Sci. doi:10.5194/hess-21-38592017

20. Rico-Ramirez MA, Liguori S, Schellart ANA (2015) Quantifying radar-rainfall uncertainties in urban drainage flow modelling. J Hydrol. doi:10.1016/j.jhydrol.2015.05.057

21. McMillan HK, Westerberg IK, Krueger T (2018) Hydrological data uncertainty and its implications. WIREs Water. doi:10.1002/wat2.1319

22. Llano MP, Vargas W (2021) Spatial and temporal variability of daily precipitation concentration in southeastern South America. Int J Climatol. doi:10.1002/joc.6759

Page 16/23 
23. Birhanu KT, Megerssa Dinka TA, Semu Ayalew O, "Optimizing Cropping Pattern Using Chance Constraint Linear Programming for Koga Irrigation Dam, Ethiopia," Irrig Drain Syst Eng, 04, 02, 2015, doi:10.4172/21689768.1000134

24. Raul SK, Panda SN, Holländer H, Billib M (2011) Integrated water resource management in a major canal command in eastern India. Hydrol Process 25(16):2551-2562. doi:10.1002/hyp.8028

25. Zeng M, Tang LH, Lin M, Wang QW (2010) Optimization of heat exchangers with vortex-generator fin by Taguchi method. Appl Therm Eng. doi:10.1016/j.applthermaleng.2010.04.009

26. Tong F, Guo P (2013) Simulation and optimization for crop water allocation based on crop water production functions and climate factor under uncertainty. Appl Math Model 37:no. 14-15. doi:10.1016/j.apm.2013.03.018., “,”, , pp. 7708-7716

27. Li M, Guo P (2014) A multi-objective optimal allocation model for irrigation water resources under multiple uncertainties. Appl Math Model 38:no. 19-20. doi:10.1016/j.apm.2014.03.043., “,”, , pp. 4897-4911

28. Mellaku MT, Reynolds TW, Woldeamanuel T, “Linear programming-based cropland allocation to enhance performance of smallholder crop production: A pilot study in Abaro Kebele, Ethiopia," Resources, 7, 4, 2018, doi:10.3390/resources 7040076

29. Abdulbaki D, Al-Hindi M, Yassine A, Abou Najm M (2017) An optimization model for the allocation of water resources. J Clean Prod. doi:10.1016/j.jclepro.2017.07.024

30. Mekonen A, Gebremeskel T, Mengistu A, Fasil E, Melkamu M (2015) Irrigation water pricing in Awash River Basin of Ethiopia: Evaluation of its impact on scheme-level irrigation performances and willingness to pay. African J Agric Res. doi:10.5897/ajar2014.9381

31. Kerebih MS, Keshari AK, "Distributed simulation-optimization model for conjunctive use of groundwater and surface water under environmental and sustainability restrictions 1 Introduction." J. of Water Resources Management, in press,2021

32. Gupta A, Kamble T, Machiwal D (2017) Comparison of ordinary and Bayesian kriging techniques in depicting rainfall variability in arid and semi-arid regions of north-west India. Environ Earth Sci. doi:10.1007/s12665017-6814-3

33. P. J. Neiman, F. M. Ralph, A. B. White, D. E. Kingsmill, and P. O. G. Persson, "The statistical relationship between upslope flow and rainfall in California's coastal mountains: Observations during CALJET," Mon. Weather Rev., 2002, doi: 10.1175/1520-0493(2002)130<1468:TSRBUF>2.0.C0;2.

34. Dinka MO, "Development and Application of Conceptual Rainfall-Altitude Regression Model: The Case of Matahara Area (Ethiopia)," in Topics in Hydrometerology, 2019

35. Sø. Thorndahl A, Korup Andersen, Larsen AB (2017) Event-based stochastic point rainfall resampling for statistical replication and climate projection of historical rainfall series. Hydrol Earth Syst Sci. doi:10.5194/hess-21-4433-2017

36. Chen $L$ et al (2018) Influence of rainfall data scarcity on non-point source pollution prediction: Implications for physically based models. J Hydrol. doi:10.1016/j.jhydrol.2018.04.044

37. Meis M, Llano MP, Rodriguez D (2020) Quantifying and modelling the ENSO phenomenon and extreme discharge events relation in the La Plata Basin. Hydrol Sci J. doi:10.1080/02626667.2020.1843655

38. Kwarteng AY, Dorvlo AS, Kumar GTV (2009) Analysis of a 27-year rainfall data (1977-2003) in the Sultanate of Oman. Int J Climatol. doi:10.1002/joc.1727

39. Wanielista MP, Yousef YA, “Stormwater management," 1992 
40. Zalina MD, Desa MNM, Nguyen VTV, Kassim AHM, "Selecting a probability distribution for extreme rainfall series in Malaysia," 2002, doi: 10.2166/wst.2002.0028

41. Liu J, Doan CD, Liong SY, Sanders R, Dao AT, Fewtrell T (2015) Regional frequency analysis of extreme rainfall events in Jakarta. Nat Hazards. doi:10.1007/s11069-014-1363-5

42. Stedinger JR, Vogel RM, Foufoula-Georgiou E, "Frequency Analysis of Extreme Events," Handb. Hydrol., 1993

43. Allen RG, Pereira LS, Raes D, Smith M, "Crop evapotranspiration: Guidelines for computing crop requirements," Irrig. Drain. Pap. No. 56, FAO, 1998, doi: 10.1016/j.eja.2010.12.001

44. Doorenboos J, Pruitt WO, Guidelines for predicting crop water requirements, Irrigation and Drainage Paper 24. 1977

45. Dastane NG, “Effective rainfall irrigated agriculture,” pp. 5-6, 1999

46. Branch M, Grace a, “Optimization Toolbox-For Use with Matlab,” MathWorks Inc, 1996

\section{Figures}

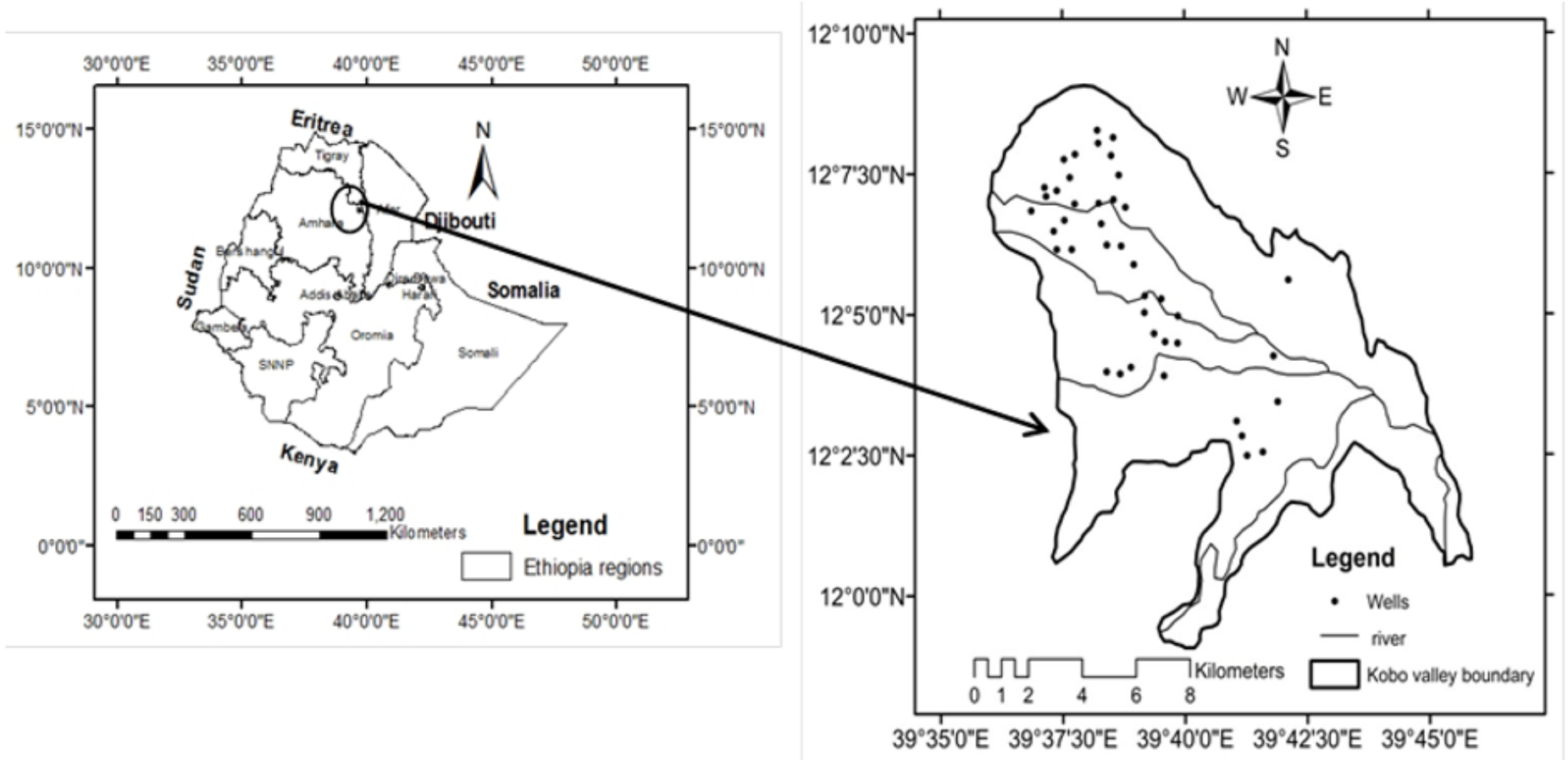

Figure 1

Location map of the study area 


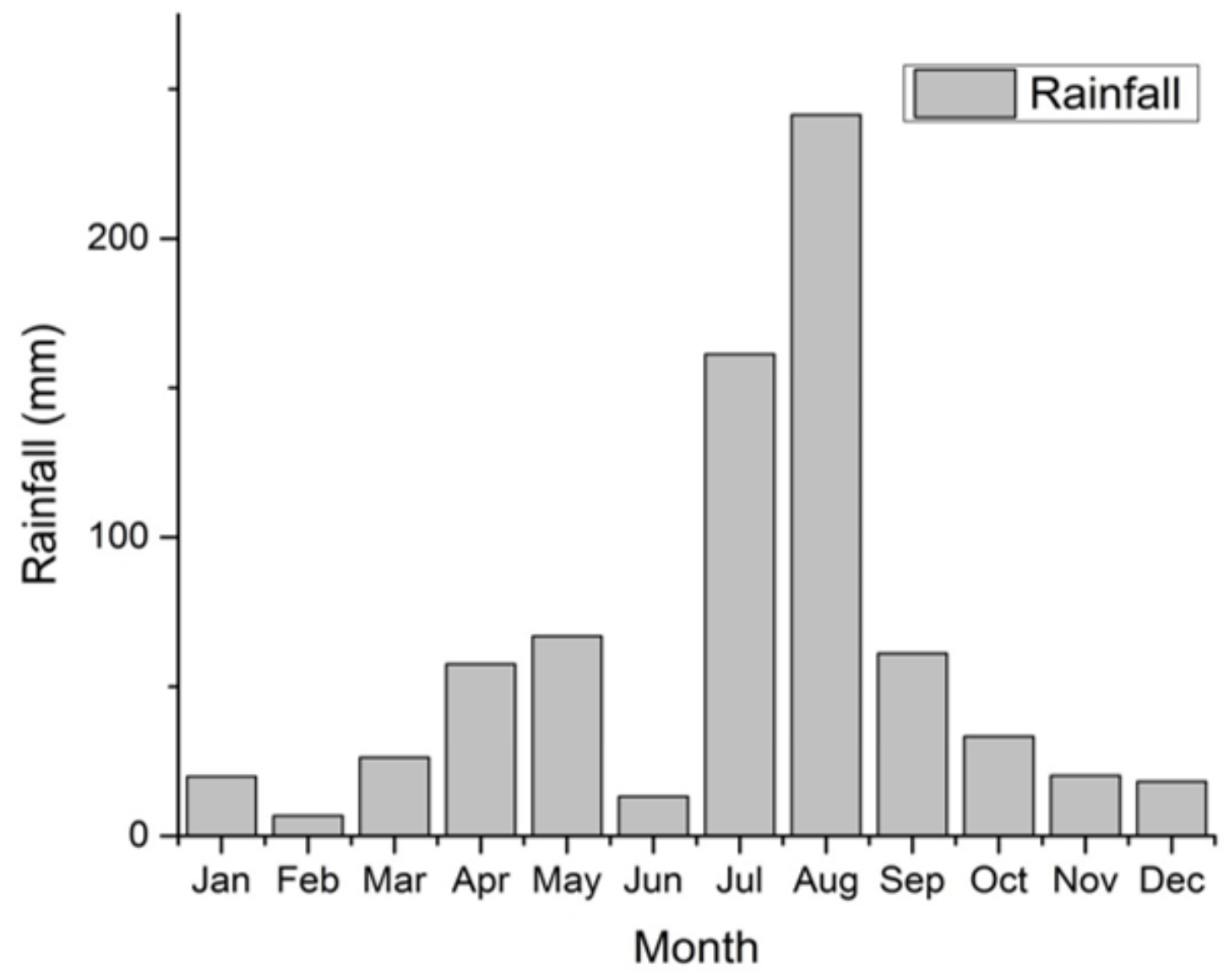

Figure 2

Average rainfall (At Kobo Observatory station, 1996-2010) 


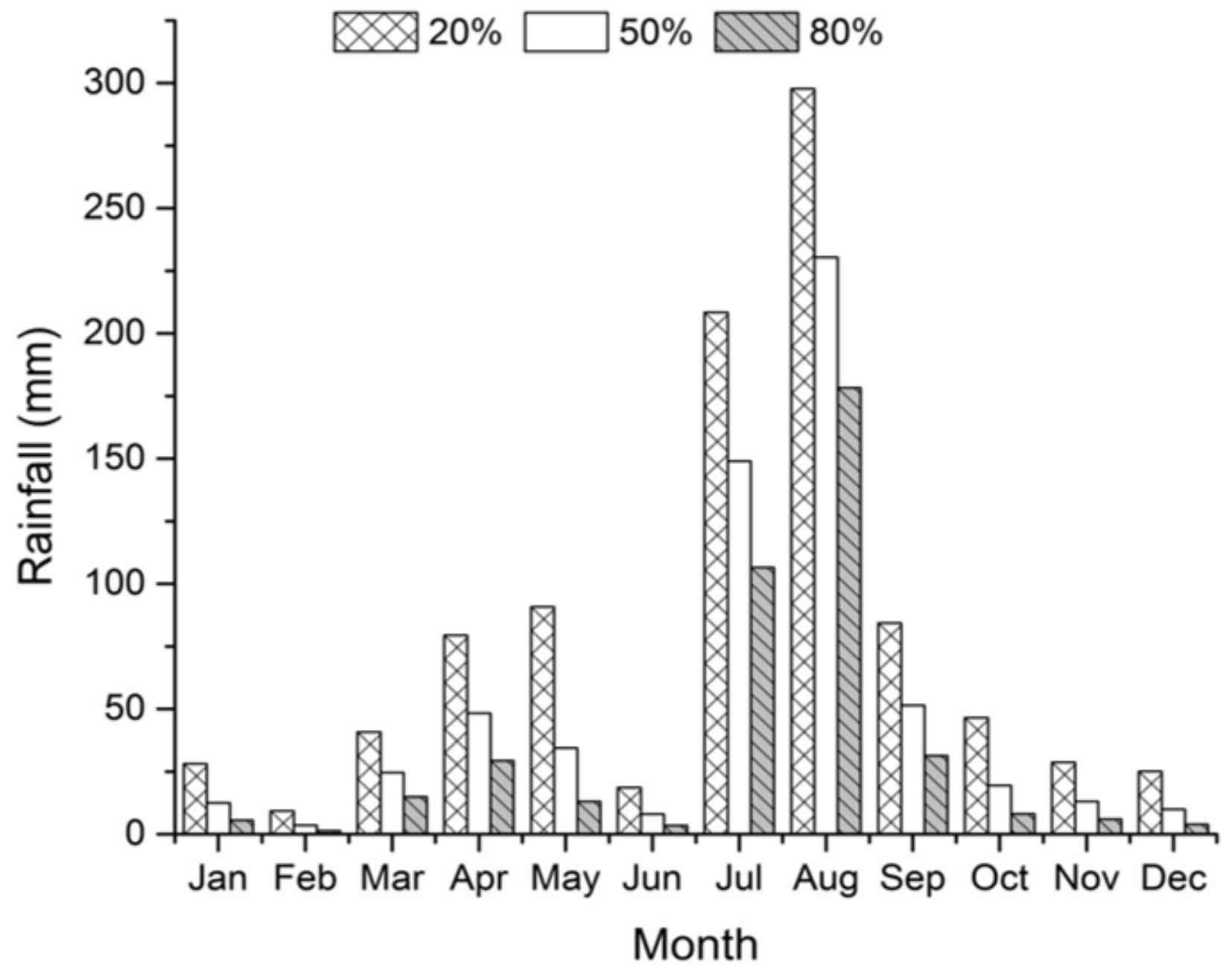

Figure 3

Monthly dependable rainfall at 80,50 and $20 \%$ probability exceedance
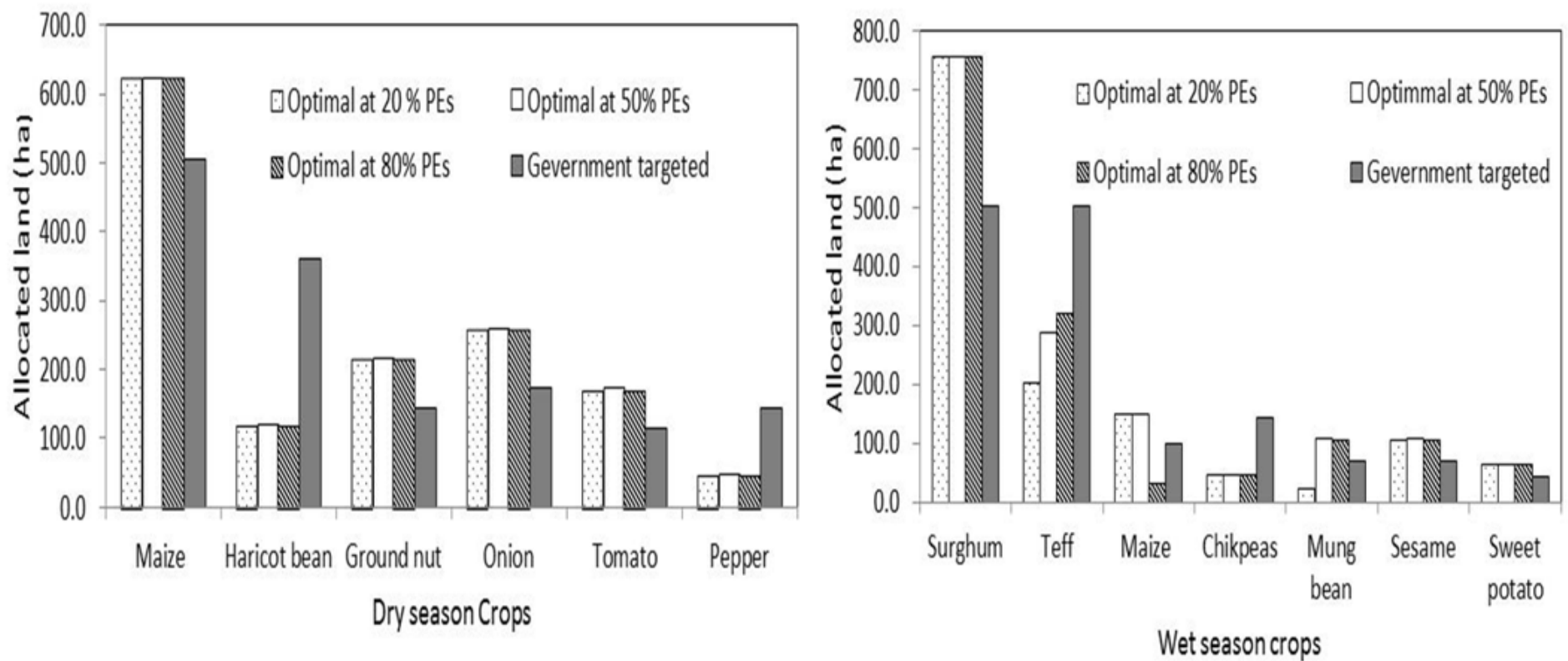

Figure 4 


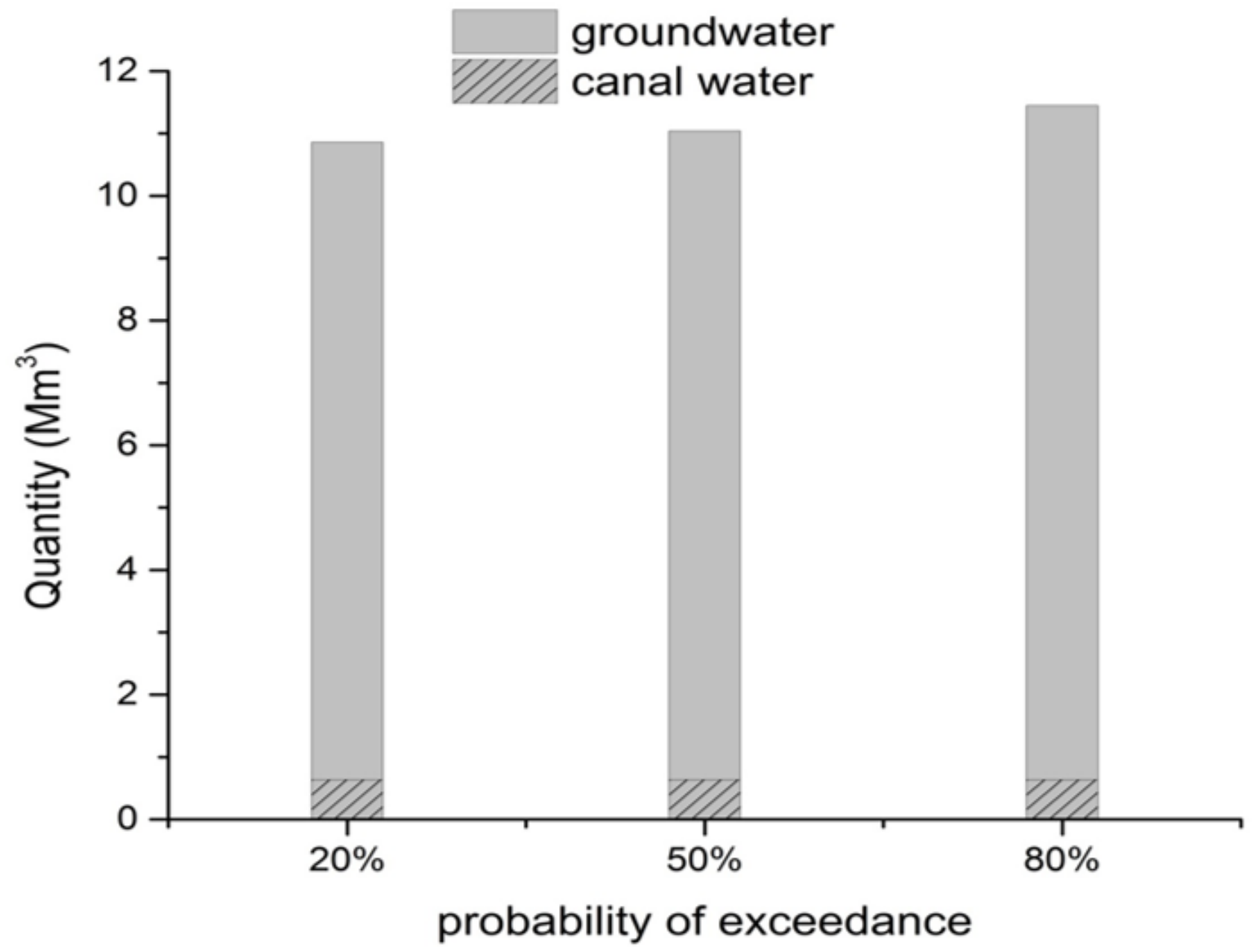

Figure 5

Optimum allocation of surface water and groundwater at different PEs during dry season 


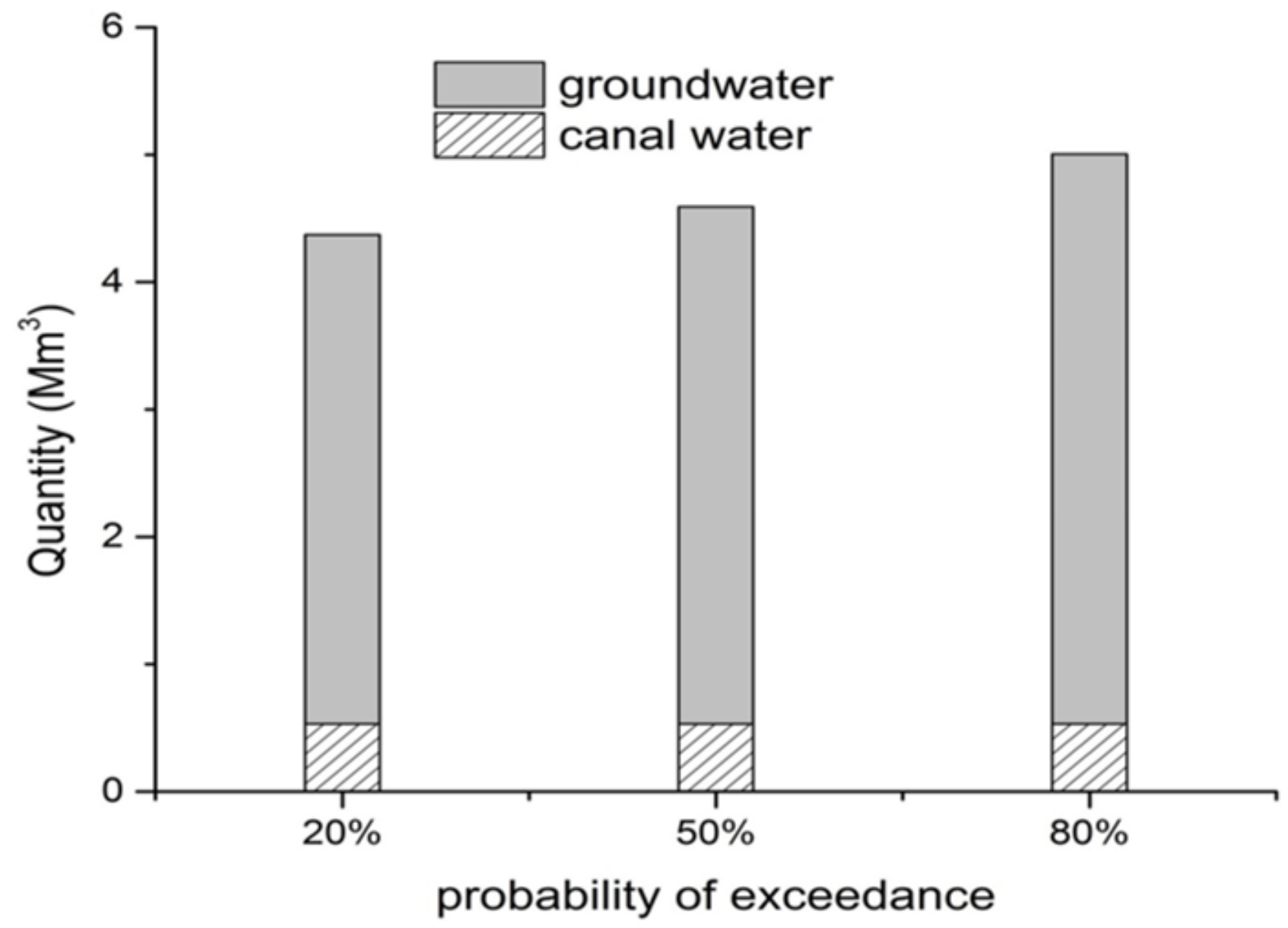

Figure 6

Optimum allocation of surface water and groundwater at different PEs during wet season 


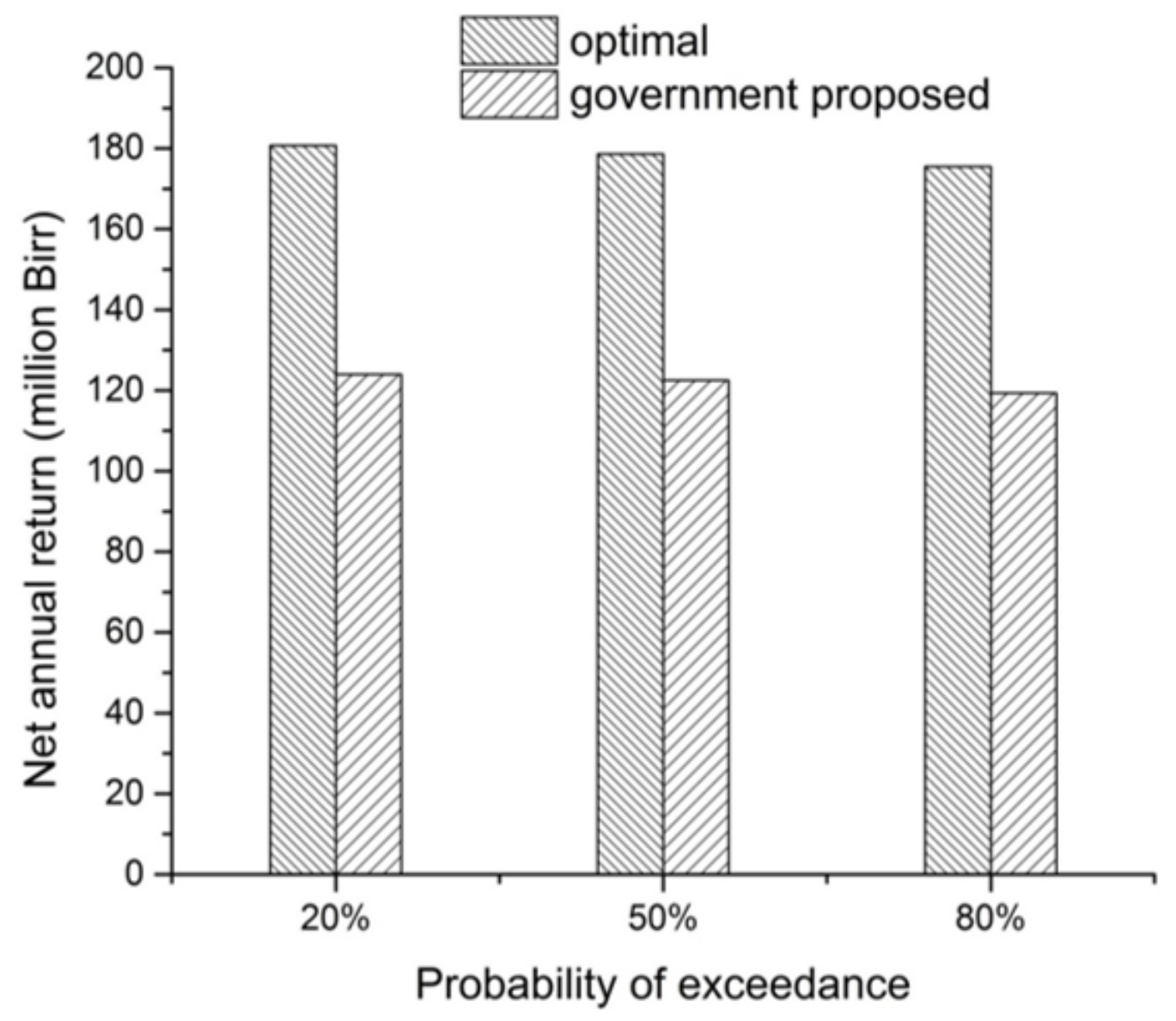

Figure 7

Comparison of net annual return with optimal cropping pattern and government proposed with different PEs 